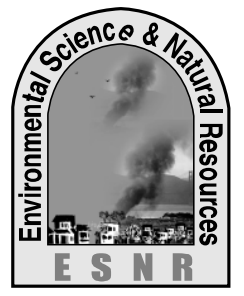

J. Environ. Sci. \& Natural Resources, 5(2): 263 - 266, 2012

ISSN 1999-7361

\title{
Perception of Environmental Education and Awareness Among Mass People: A Case Study of Tangail District
}

\author{
S. A. Mamun ${ }^{1}$, A. Nessa ${ }^{1}$, M. Aktar ${ }^{2}$, M. R. Hossain ${ }^{1}$ and A. S. M. Saifullah ${ }^{1}$ \\ ${ }^{1}$ Department of Environmental Science and Resource Management, \\ Mawlana Bhashani Science and Technology University, Santosh, Tangail, 1902, Bangladesh \\ ${ }^{2}$ Department of Soil, Water and Environment, University of Dhaka, Dhaka-1000, Bangladesh
}

\begin{abstract}
At present environmental education is emerging across the globe although this is a quite new phenomenon in Bangladesh. The present study was attempted to know about the environmental education and awareness among the mass people of Tangail town. In order to conduct this research, a questionnaire survey was carried out and interview was undertaken among 100 respondents in Tangail District. This paper describes some findings to understand the status of environmental awareness among people of different age groups of Tangail district. Moreover, this paper enables to provide some suggestions to extend environmental education and awareness to make a decent and ethical life as well as to keep the environment sustainable.
\end{abstract}

Key words: Environmental education, People, Sustainability,Tangail municipal area

\section{Introduction}

Bangladesh is one of the most densely populated countries with limited land area (about 0.06 ha/ person) (Ali, 1995 and UNDP, 1995). Because of increased population pressure, huge amount of natural resources are being used every day and the quality of the environment is deteriorating directly and indirectly through various anthropogenic as well as natural activities. Nevertheless, this environment deterioration has ultimately posed a threat to human civilization on global arena (Kabir and Mahmud, 2009). For instance, in recent years fresh water scarcity on a global scale, deforestation, degradation of coastal and marine areas, soil depletion and loss of biodiversity have become a major concern. Air and water pollution have reached such levels that have already resulted serious health hazards and negative impact on the environment as well as inevitably influence the prospects of long-term economic growth (Krishnamacharyulu and Reddy, 2005).

According to UN Climate Panel (2007), the melting of Himalayan glaciers could have serious consequences since over 800 million residents; almost half of the Indian and Bangladeshi population relies on the Ganges and the Brahmaputra river basins for water supply. With Himalayan glaciers melting, its eastern islands sinking and freak rain flooding deserts, environmentalists opine global warming is already taking its toll on one of most populous Asian nation, Bangladesh.

Currently, the steady global environment deterioration is a matter of great concern and gives emphasis on environmental education and awareness based courses and trainings. Environmental education certainly, a powerful vehicle bringing about change, a Panacea of all evils and a potent weapon for prevention plays a central role in the society. The need of the hour is to make people sensitive towards nature through a strong programme of environmental education (Nachimuthu and Vijayakumari, 1993). Environmental education is not only some literatures and textbook full of hypothesis but also the remedy of the upcoming disaster. In order to protect and conserve the environment, enabling people to lead quality life, emphasis has been given to environmental education in both formal and nonformal system of education.

In 1970, the International Union for Conservation of Nature (IUCN) called an international working meeting of its "Commission on Education" to discuss and work out Environmental Education curriculum for school. UNESCO (1974) reported environmental education as a tool of environment protection rather recognizes this as a subdivision of science based study. Another research coincided by (Sytnick 1985) demonstrated environmental education as a lifelong educational process. Although the global environment is at risk and environmental education is one of the prerequisite of its remedy, this is just three decades that environmental issues might be a concern for the global sustainable development. Thus, open discussion on environment education at national and international level such as conferences and workshops could make it possible to understand common people about the necessity of environmental education and awareness and its significance in practical life (Rao, 2010).

Recently, almost all developed world are concern about their environment and give priority on environmental education. Meanwhile Bangladesh lag far away from environmental studies in her formal education system and this is a quite new concept in Bangladesh (Kabir and Mahmud, 2009). The 
principal aim of this research was to know about the environmental education and awareness among the mass people of Tangail municipal area according to their age levels.

\section{Materials and methods}

This study was conducted in Tangail District to collect the required information on various aspects of the study following a questionnaire survey. An interview schedule was undertaken among 100 participants to satisfy the objective of this research. The information recorded from the interviewee added valuable information about environmental education and awareness and follow similarities with literature review. After obtaining required information, the data were analyzed by using Microsoft office package.

\section{Results and Discussion}

\section{Drinking water source greatly influence water borne disease}

The Table 1 describes that most of the respondents mentioned that they are affected less by water borne diseases when drink water from tubewell. On the contrary, the data showed that supply water causes disease mostly. Thus the level of disease affected people is notably low on Tubewell water user than other two water source users.

Table 1: Relation between drinking water and water borne disease

\begin{tabular}{|c|l|l|l|}
\hline \multirow{2}{*}{$\begin{array}{c}\text { Drinking water } \\
\text { source }\end{array}$} & \multicolumn{2}{|l|}{$\begin{array}{l}\text { Affected water } \\
\text { borne disease }\end{array}$} & Total respondents \\
\cline { 2 - 4 } & No & Yes & \\
\hline $\begin{array}{l}\text { Tubewell } \\
\text { River|Pond } \\
\text { water }\end{array}$ & 42 & 20 & 62 \\
$\begin{array}{c}\text { Supply water } \\
\text { Total }\end{array}$ & 13 & 24 & 37 \\
\hline
\end{tabular}

\section{Age and water borne disease affected rate}

The Table 2 showed a relationship how local people of Tangail municipal area are affected by waterborne diseases according to age group. The table represent that people who are in the age between 31-55 years old are vulnerable mostly to waterborne diseases. This may be due to the use of water for drinking purposes from unsafe sources and probably the water was not pure drinking water.
Table 2: Relation between age and water borne disease

\begin{tabular}{|ll|l|l|l|}
\hline & & \multicolumn{2}{|l|}{$\begin{array}{l}\text { No Affected by water } \\
\text { borne disease }\end{array}$} & Total \\
\hline & & No & \multicolumn{1}{l|}{ Yes } & \\
\hline Age & $10-18$ & 8 & 7 & 15 \\
& $19-30$ & 15 & 18 & 33 \\
& $31-55$ & 15 & 22 & 37 \\
& $56-$ More & 7 & 8 & 15 \\
Total & & 45 & 55 & 100 \\
\hline
\end{tabular}

Contribution to minimizing pollution according to Sex

The Table 3 demonstrates how different gender groups contribute to reduce environment pollution through their awareness. This table described that women's contribution was more than male to keep the environment safe and clean. The possible explanation is that women usually look after house hold activity and try to keep their family healthy and happy. From this point of view, they try to produce less pollution. However, if they could able to receive any formal environmental education or training, it would make them more aware about quality of environment and its diverse benefits.

Table 3: Relation between sex and pollution control contribution

\begin{tabular}{|c|l|l|}
\hline \multirow{2}{*}{ Gender } & \multicolumn{2}{|c|}{ Contribution to minimize pollution } \\
\cline { 2 - 3 } & No & Yes \\
\hline Male & $49.2 \%$ & $50.8 \%$ \\
\hline Female & $42 \%$ & $58 \%$ \\
\hline
\end{tabular}

\section{Concern about environmental pollution of different ages people}

It has been noticed from Table 4 that among the participants $85 \%$ people who are concern about environment pollution are in the age group 19-30 years. They contributed maximum to keep environment pollution free while the age group of 56 or more were not concern even did not show their interest about environmental issues. 
Table 4: Relation between age and concern of pollution at different ages

\begin{tabular}{|ll|l|l|l|}
\hline & & \multicolumn{2}{|c|}{ Pollution Concern } & Total \\
\hline & & No & Yes & \\
\hline Age & $10-18$ & $5(34 \%)$ & $10(67 \%)$ & 15 \\
& $19-30$ & $5(15 \%)$ & $28(85 \%)$ & 33 \\
& $31-55$ & $12(34 \%)$ & $25(67 \%)$ & 37 \\
& $56-$ More & $8(53 \%)$ & $7(47 \%)$ & 15 \\
Total & & 30 & 70 & 100 \\
\hline
\end{tabular}

Water borne disease activity on different sanitation system

According to Table 5 it has revealed clearly that maximum people of Tangail district are concern about their sanitation system. It has been observed from following table that people who use open toilet are more in danger to water borne disease because they dump their waste into nearby place, which's washed away to the water body, later these water is used by the people.

Table 5: Relation between water borne disease and sanitation system

\begin{tabular}{|c|c|c|c|}
\hline \multirow[b]{2}{*}{ Sanitation system } & \multicolumn{2}{|c|}{$\begin{array}{l}\text { Affected water borne } \\
\text { disease }\end{array}$} & \multirow[t]{2}{*}{$\begin{array}{l}\text { Total } \\
\text { respondents }\end{array}$} \\
\hline & No & Yes & \\
\hline Open & 0 & 4 & 4 \\
\hline Closed & 45 & 51 & 96 \\
\hline Total & 45 & 55 & 100 \\
\hline
\end{tabular}

Table 6: Relation of Age and Sex with water source, water borne disease, arsenic pollution concern and global warming concern.

\begin{tabular}{|c|c|c|c|c|c|c|c|c|c|c|}
\hline & & \multicolumn{3}{|c|}{ Drinking water source } & \multicolumn{2}{|c|}{$\begin{array}{c}\text { Affected water borne } \\
\text { disease }\end{array}$} & \multicolumn{2}{|c|}{ Arsenic pollution concern } & \multicolumn{2}{|c|}{$\begin{array}{c}\text { Global } \\
\text { warming } \\
\text { concern }\end{array}$} \\
\hline & & Tubewell & $\begin{array}{l}\text { River/Pond } \\
\text { Water }\end{array}$ & $\begin{array}{l}\text { Supply } \\
\text { water }\end{array}$ & No & Yes & No & Yes & No & Yes \\
\hline Age & $\begin{array}{l}10-18 \\
19-30 \\
31-55 \\
56-\text { more }\end{array}$ & $\begin{array}{l}9 \\
22 \\
21 \\
10\end{array}$ & 1 & $\begin{array}{l}6 \\
10 \\
17 \\
4\end{array}$ & $\begin{array}{r}8 \\
15 \\
15 \\
7\end{array}$ & $\begin{array}{l}7 \\
18 \\
22 \\
8\end{array}$ & $\begin{array}{l}9 \\
6 \\
15 \\
8\end{array}$ & $\begin{array}{l}6 \\
27 \\
22 \\
7\end{array}$ & $\begin{array}{l}9 \\
12 \\
14 \\
11\end{array}$ & $\begin{array}{l}6 \\
21 \\
23 \\
4\end{array}$ \\
\hline Sex & Male & 42 & 1 & 22 & 28 & 37 & 23 & 42 & 29 & 36 \\
\hline & Female & 20 & - & 15 & 17 & 18 & 15 & 20 & 17 & 18 \\
\hline
\end{tabular}

\section{Present status of environmental awareness in Tangail town}

The Table 6 shows the environmental concern noticed among different ages and sex groups of Tangail area and revealed that the maximum environment aware group is $31-55$ years age group whether people who are over 56 respond very poor regarding environment. In addition, male participants showed more interest in all global environmental issues including water sources, pollution as well as global warming. In addition, this study stated that people of almost all age groups of Tangail town aware of environmental pollution although many of them do not have any idea about the term Global warming. The concern on Arsenic pollution is high in middle aged male respondents (31-55 years people) because they have got more opportunity and keep in touch with news paper and outdoor communication rather than women. A major group of participants use Tubewell water for drinking water source that results low water borne disease and indicate their serious attitude toward environment.

It has been revealed from Table 7 that respondents in the age group of 19-30 years old respond positively to control global environmental pollution and improved waste management systems. In addition, male participants respond more than female respondents regarding pollution control and waste management systems. 
Table 7: Relation of age and sex with pollution concern, contribution to pollution control, satisfaction with municipal waste management and sanitation system

\begin{tabular}{|c|c|c|c|c|c|c|c|c|c|}
\hline & & \multicolumn{2}{|c|}{ Pollution Concern } & \multicolumn{2}{|c|}{$\begin{array}{l}\text { Contribution to pollution } \\
\text { control }\end{array}$} & \multicolumn{2}{|c|}{$\begin{array}{l}\text { Satisfy with municipal } \\
\text { waste management system }\end{array}$} & \multicolumn{2}{|c|}{ Sanitation system } \\
\hline & & No & Yes & No & Yes & No & Yes & Open & Closed \\
\hline Age & $\begin{array}{l}10-18 \\
19-30 \\
31-55 \\
56-\text { more }\end{array}$ & $\begin{array}{l}5 \\
5 \\
12 \\
8\end{array}$ & $\begin{array}{l}10 \\
28 \\
25 \\
7\end{array}$ & $\begin{array}{l}7 \\
18 \\
17 \\
5\end{array}$ & $\begin{array}{l}8 \\
15 \\
20 \\
10\end{array}$ & $\begin{array}{l}11 \\
26 \\
25 \\
6\end{array}$ & $\begin{array}{l}4 \\
7 \\
12 \\
9\end{array}$ & $\begin{array}{l}1 \\
1\end{array}$ & $\begin{array}{l}14 \\
32 \\
37 \\
13\end{array}$ \\
\hline Sex & Male & 21 & 44 & 32 & 33 & 45 & 20 & 4 & 61 \\
\hline & Female & 9 & 26 & 15 & 20 & 23 & 12 & & 35 \\
\hline
\end{tabular}

Furthermore, the present research has revealed those issues arise from the literature review as well as from the interview of the survey. Regarding environmental awareness present research discussed about some factual information about environmental education and awareness among various age groups. It has been noticed that young people 19-33 years old people are more concern about current environmental issues. During the survey period, almost all respondents mentioned to create an opportunity to learn environmental education in formal education system not only in Tangail district rather in entire Bangladesh. They added that although Tangail is a municipal area, most of the people here are interested about environment particularly male people. In these circumstances, mass media campaign and advertising might be useful to make people aware since this is quite difficult for old people to go to school and have lessons.

\section{Conclusion}

Until recent year, environmental education and awareness is in its initial stage in Bangladesh. However, the whole environment is at risk recently because of booming population. These mass people are exposed to different types of pollutions and arsenic contamination that may lead to a great threat to them. According to present research, most of the people of Tangail Municipal area have traditional knowledge about environmental issues although environmental education is important due to present global agenda of sustainable development. Deployment of environmental expertise in public and private environment management sectors to teach and train people about environment protection and conservation to pressing sustainable environment within limited opportunities and limitations will improve the present environmental condition of Bangladesh.

\section{References}

Ali, A. M. S. 1995. Population Pressure,

Environmental Constraints and Agricultural Changes in Bangladesh: Examples from Three Agro-Ecosystems. Agriculture, Ecosystems, and Environment, 55: 95-109.

Kabir, M. H. and Mahmud, M. S. 2009. Environmental Education in Bangladesh: Institutional Practices and Opportunities. Development Compilation, 2 (1): 1-5.

Krishnamaracharyulu, V. and Reddy, G. S. 2005. Environmental Education: Aims and Objectives of Environmental Education: Importance of Environmental Education. Hyderabad: Neelkamal Publications Pvt. Ltd.

Nachimuthu, K. and Vijayakumari, G. 1993. An urgent need for environmental education, Edu. Rev.,3:11-14.

Rao, K. 2010. Environmental Awareness To D.Ed. Students. Referred Research Journal, 2.

Sytnic, K. M. 1985. Living in the Environment: A source Book for Environmental Education (English Translator), Paris UNESCO.

UNESCO, 1974. Reports of the Seminar on Environmental Education. Finished National Commission for UNESCO.

United Nations Climate Panel (UNCP), 2007. Report on scientific findings for policy makers. Deccan Herald, 2 (34): 1.

United Nations Development Programme (UNDP), 1995. UNDP's 1995 Report on Human Development in Bangladesh: Environment. UNDP: Dhaka, Bangladesh. 